九州大学学術情報リポジトリ

Kyushu University Institutional Repository

\title{
L-Ornithine attenuates corticotropin-releasing factor-induced stress responses acting at GABA A receptors in neonatal
}

Kurata, Koji

Laboratory of Regulation in Metabolism and Behavior, Graduate School of Bioresource and Bioenvironmental Sciences, Kyushu University

Shigemi, Kazutaka

Laboratory of Regulation in Metabolism and Behavior, Graduate School of Bioresource and Bioenvironmental Sciences, Kyushu University

Tomonaga, Shozo

Laboratory of Advanced Animal and Marine Bioresources, Graduate School of Bioenvironmental Sciences, Kyushu University

Aoki, Mami

Healthcare Products Development Center, KYOWA HAKKO BIO CO., LTD

他

http://hdl. hand le. net/2324/25435

出版情報 : Neuroscience. 172, pp. 226-231，2011-01-13. Elsevier バージョン:

権利関係: (C) 2011 Elsevier Ltd. 


\section{L-Ornithine attenuates corticotropin-releasing factor-induced stress responses acting at $\mathrm{GAB}_{\mathrm{A}}$ receptors in neonatal chicks}

Koji Kurata ${ }^{1}$, Kazutaka Shigemi ${ }^{1}$, Shozo Tomonaga ${ }^{2}$, Mami Aoki $^{3}$, Koji Morishita ${ }^{3}$, D. Michael Denbow ${ }^{4}$, Mitsuhiro Furuse ${ }^{1}$

${ }^{1}$ Laboratory of Regulation in Metabolism and Behavior, Graduate School of Bioresource and Bioenvironmental Sciences, Kyushu University, Fukuoka, Japan

${ }^{2}$ Laboratory of Advanced Animal and Marine Bioresources, Graduate School of Bioenvironmental Sciences, Kyushu University, Fukuoka, Japan

${ }^{3}$ Healthcare Products Development Center, KYOWA HAKKO BIO CO., LTD, Ibaraki, Japan

${ }^{4}$ Department of Animal and Poultry Sciences, Virginia Polytechnic Institute and State University, Blacksburg, VA 24061-0306, USA

\section{Correspondence should be addressed to: Mitsuhiro Furuse}

Laboratory of Regulation in Metabolism and Behavior, Graduate School of Bioresource and Bioenvironmental Sciences, Kyushu University, Fukuoka 812-8581, Japan

Tel. $(81)(92) 642-2953$

Fax $(81)(92) 642-2953$

E-mail: furuse@brs.kyushu-u.ac.jp 
Abbreviations: ANOVA, analysis of variance; CRF, corticotropin-releasing factor; DMSO, dimethyl sulfoxide; GABA, $\gamma$-aminobutyric acid; i.c.v., intracerebroventricular; NMDA, $N$-Methyl- $D$-aspartate; S.E.M., standard error of the mean. 


\begin{abstract}
Intracerebroventricular (i.c.v.) injection of L-ornithine has been shown to have sedative and hypnotic effects on neonatal chicks exposed to acute stressful conditions. To clarify the mechanism, we conducted three experiments under strengthened stressful conditions with corticotropin-releasing factor (CRF). In Experiment 1, the effect of i.c.v. injection of CRF, L-ornithine $(0.5 \mu \mathrm{mol})$ or CRF with L-ornithine on the stressful response of chicks was investigated. Compared with the vehicle control, CRF increased distress vocalizations and the time spent in active wakefulness. L-Ornithine increased the time spent in sleeping posture, even following stimulation with CRF. In Experiment 2, dose-dependent effects of L-ornithine were investigated using i.c.v. administration with vehicle, CRF alone or CRF plus L-ornithine $(0.125,0.25$ or $0.5 \mu \mathrm{mol})$. L-Ornithine decreased the CRF-stimulated distress vocalizations in a dose-dependent manner. In Experiment 3, the chicks were injected i.c.v. with either CRF, CRF plus L-ornithine $(0.5 \mu \mathrm{mol}), \mathrm{CRF}$ plus the $\gamma$-aminobutyric acid $(\mathrm{GABA})_{\mathrm{A}}$ receptor antagonist picrotoxin or L-ornithine with picrotoxin. The sedative and hypnotic effects induced by L-ornithine were blocked with co-administration of picrotoxin. These results suggest that L-ornithine could attenuate CRF-stimulated stress behaviors acting at $\mathrm{GABA}_{\mathrm{A}}$ receptors.
\end{abstract}

Key words: L-ornithine, corticotropin-releasing factor, $\mathrm{GABA}_{\mathrm{A}}$ receptors, stress, behavior 


\section{Introduction}

L-Arginine is classified as an essential amino acid for birds, carnivores and young mammals and a conditionally essential amino acid for adult humans. Recently, we found that i.c.v. injection of L-arginine induced sedative and/or hypnotic effects in chicks exposed to a social isolation stress (Suenaga et al., 2008a). L-Arginine exerts its metabolic roles through the production of diverse metabolites including nitric oxide (NO), L-ornithine, polyamines, L-proline, L-glutamate, L-glutamine, creatine and agmatine (Morris, 2004). Among these metabolites, i.c.v. injections of L-ornithine (Suenaga et al., 2008b), L-proline (Hamasu et al., 2009a, b), and L-glutamate (Yamane et al., 2009) had a similar function as observed by i.c.v. injection of L-arginine (Suenaga et al., 2008a). However, the contribution of NO (Suenaga et al., 2008a) and agmatine (Suenaga et al., 2008b) to these effects seems to be negligible.

L-Ornithine is converted to pro-proliferative polyamine via ornithine decarboxylase. Polyamines such as putrescine, spermidine and spermine are small ubiquitous cationic molecules required for cell growth and homeostasis (Pegg and McCann, 1982; Tabor and Tabor, 1984). Polyamines, unlike L-ornithine, do not induce a hypnotic effect, whereas only putrescine caused a sedative effect among the three polyamines (Kurauchi et al., 2010). Several putative metabolites from L-ornithine, L-citrulline and D-ornithine also were investigated (Kurauchi et al., 2009). D-Ornithine weakly attenuated the stress responses while L-citrulline had no effect. Therefore, it appears that the sedative and hypnotic effect of L-ornithine was mainly induced by L-ornithine itself (Kurauchi et al., 2010). However, the mechanism by which i.c.v. administered L-ornithine induces sedative and hypnotic effects was unclear.

In the present study, we used the social separation stress model. This stress model 
is frequently used for the study of anxiety. Chicks feel comfortable when living in a group, but develop anxiety when isolated. Social separation stress increases vocalization of chicks (Feltenstein et al., 2003). Therefore, this social separation stress paradigm has been used for developing anxyolitic agents using vocalization as an indicator of their effectiveness. In addition, the magnitude of the anxiety induced by social separation stress was strengthened by i.c.v. CRF (Zhang et al., 2001a, b, 2003, 2004). CRF is a 41-amino acid peptide hormone produced in the hypothalamus. CRF has multiple biologicaleffects and plays a central regulatory role in the hypothalamic-pituitary-adrenal axis. CRF rapidly mobilizes the organism for responses to stressors and also stimulate the central nervous system respond to environmental changes (Richard et al., 2002). Further, so far, we have demonstrated that L-pipecolic acid, an L-lysine metabolite (Takagi et al., 2003), creatine (Koga et al., 2005), (-)-epigallocatechin gallate (Adachi et al., 2006) and L-serine (Shigemi et al., 2008) had a sedative and hypnotic effect for social isolation stress, and all these metabolites function though the $\mathrm{GABA}_{\mathrm{A}}$ receptor. Therefore, in Experiment 3, we investigated the relationships between the function of L-ornithine on the stress response and whether it involves the $\mathrm{GABA}_{\mathrm{A}}$ receptor.

Taken together, the purpose of this study was to further elucidate the mechanism of the sedative and hypnotic effects of L-ornithine. Therefore, the contribution of inhibitory neurotransmission via the $\mathrm{GABA}_{\mathrm{A}}$ receptor was investigated using the social separation stress model further enhanced by i.c.v. CRF.

\section{Experimental procedures}

\subsection{Animals}


One-day-old male layer chicks (Julia) were purchased from a local hatchery (Murata Hatchery, Fukuoka, Japan) and housed in a windowless room at a constant temperature of $30 \pm 1{ }^{\circ} \mathrm{C}$. Continuous lighting was provided. Food (Toyohashi Feed and Mills Co. Ltd., Aichi, Japan) and water were freely accessible. Chicks were reared in a group (20-25 per cage) until the start of the experiment. On the day of the experiment, chicks (4- or 5-day-old) were assigned to treatment groups based on their body weight in order to produce uniform treatment groups, and the number of animals used in each group was kept to a minimum while still ensuring adequate statistical power. Experimental procedures followed the guide for Animal Experiments in Faculty of Agriculture and in the Graduate Course of Kyushu University and the Low (No.105) and Notification (No.6) of the Government and were in accordance with recommendations of the National Research Council (1994).

\subsection{Preparation of drugs}

L-Ornithine monohydrochloride was provided by KYOWA HAKKO BIO CO., LTD. (Tokyo, Japan). Rat CRF was purchased from Peptide Institute, Inc. (Osaka, Japan). Dimethyl sulfoxide (DMSO) and picrotoxin were purchased from Sigma (St. Louis, MO). Drugs were dissolved in $0.85 \%$ saline containing $0.1 \%$ Evans Blue or $0.85 \%$ saline containing 5\% DMSO and 0.1\% Evans Blue. In Experiments 1 and 2, control groups were given the vehicle. In Experiment 3, control group was given the same vehicle with CRF.

\subsection{I.c.v. injection and experimental design}

The i.c.v. injections were made using a microsyringe according to the method of 
Davis et al. (1979) and Koutoku et al. (2005). The stress and pain of this method is minimal as described elsewhere (Koutoku et al., 2005). The injected volume was $10 \mu 1$. In Experiment 1, chicks were administrated either vehicle, CRF (0.01 $\mu \mathrm{g})$, L-ornithine $(0.5 \mu \mathrm{mol})$ or CRF plus L-ornithine. The dose of L-ornithine was based on Suenaga et al. (2008b), and the dose of CRF was based on Saito et al. (2005a). In Experiment 2, chicks were injected either vehicle, CRF $(0.01 \mu \mathrm{g})$ or CRF plus L-ornithine $(0.125,0.25$ or $0.5 \mu \mathrm{mol})$. In Experiment 3, chicks were administrated either CRF (0.01 $\mu \mathrm{g})$, CRF plus L-ornithine $(0.5 \mu \mathrm{mol})$, CRF plus picrotoxin $(500 \mathrm{ng})$ or CRF plus L-ornithine plus picrotoxin. The dose of picrotoxin was based on Adachi et al. (2006). After injection, chicks were immediately placed in an acrylic monitoring cage $(40 \mathrm{~cm} \times 30 \mathrm{~cm} \times 20 \mathrm{~cm})$, and behavioral observations were made for $10 \mathrm{~min}$. During this period, chicks were deprived of water and diet. Chick vocalizations were simultaneously recorded using Windows Media Player (Microsoft Corporation, Washington, USA) software, and the number of distress vocalizations were counted using Gretchen software (Excla Inc., Japan). Video cameras were positioned to record the behavior of chicks from three different directions on digital versatile discs. Based on the method by van Luijtelaar et al. (1987), chick behaviors were classified into four categories: (1) active wakefulness; (2) standing/sitting motionless with eyes opened; (3) standing motionless with eyes closed; and (4) sitting motionless with head drooped (sleeping posture). The monitoring systems were set in a separate room to avoid disturbing the animals. At the conclusion of the experiments, the birds were decapitated following an overdose of sodium pentobarbital. The brains were removed and the location of the Evans Blue dye was confirmed. Data from chicks without dye in the lateral ventricle were excluded from analysis. 


\subsection{Statistical analysis}

In Experiments 1 and 3, data were statistically analyzed by two-way analysis of variance (ANOVA). In Experiment 2, one-way ANOVA was used. In addition, regression analysis was used for dose of L-ornithine and distress vocalizations over time for various behavioral categories in Experiment 2. Tukey-Kramer test was used as a post hoc test and significant differences implied $\mathrm{P}<0.05$. Data were analyzed using the statistical program StatView Version 5.0 (SAS Institute, Cary, USA, 1998). Values are presented as means \pm S.E.M. All data were first subjected to Grubs-Smirnov rejection test to eliminate outliers. Then remaining data were used.

\section{Results}

Fig. 1 shows the effect of i.c.v. injection of CRF and L-ornithine on the number of distress vocalizations in chicks during the $10 \mathrm{~min}$ of social separation stress just after i.c.v. injection (Experiment 1). $\operatorname{CRF}[\mathrm{F}(1,22)=4.304, \mathrm{P}<0.05]$ enhanced while L-ornithine $[\mathrm{F}(1,22)=52.552, \mathrm{P}<0.0001]$ significantly decreased the number of distress vocalizations. There was no significant interaction between CRF and L-ornithine [F (1, $22)=3.931, \mathrm{P}>0.05]$. Distress vocalizations induced by social isolation stress with or without i.c.v. CRF were clearly attenuated by L-ornithine.

Table 1 shows the effect of CRF and L-ornithine on various behavioral categories of chicks during the 10 min behavioral observation under social separation stress. CRF significantly increased $[\mathrm{F}(1,22)=4.750, \mathrm{P}<0.05]$ while L-ornithine decreased $[\mathrm{F}(1,22)$ $=60.371, \mathrm{P}<0.0001]$ active wakefulness. No significant $[\mathrm{F}(1,22)=4.019, \mathrm{P}>0.05]$ interaction between CRF and L-ornithine was detected. In addition, L-ornithine 
significantly $[\mathrm{F}(1,22)=63.261, \mathrm{P}<0.0001]$ increased the time for sleep-like behavior irrespective of the presence of CRF.

Fig.2 shows the effect of i.c.v. injection of several doses of L-ornithine with CRF on the number of distress vocalizations in the chicks during the $10 \mathrm{~min}$ of social separation stress just after i.c.v. injection (Experiment 2). L-Ornithine significantly [F $(4,28)=13.363, \mathrm{P}<0.001)]$ decreased the number of distress vocalizations, and a negative correlation $[\mathrm{P}<0.05]$ between the dose of L-ornithine and the number of distress vocalizations was detected. Table 2 shows the effect of i.c.v. injection of several doses of L-ornithine with CRF on various behavioral categories of chicks during the 10 min behavioral observation under social separation stress. L-Ornithine decreased active wakefulness in a dose-dependent manner $(\mathrm{P}<0.05)$ under $\mathrm{CRF}$ stimulation. The low dose $(0.125 \mu \mathrm{mol})$ of L-ornithine also increased the time spent standing/sitting motionless with eyes open compared to the group receiving CRF alone. The time for sleeping posture was significantly increased by the highest level of L-ornithine.

Fig. 3 shows the effect of i.c.v. injection of CRF and L-ornithine with or without picrotoxin on the number of distress vocalizations in chicks during the 10 min under social separation stress (Experiment 3). L-Ornithine decreased the number of distress vocalizations $[\mathrm{F}(1,27)=7.674, \mathrm{P}<0.05]$ while picrotoxin caused an increase when compared to the CRF plus L-ornithine group $[\mathrm{F}(1,27)=21.044, \mathrm{P}<0.0001]$. A significant interaction between L-ornithine and picrotoxin $[\mathrm{F}(1,27)=18.376, \mathrm{P}<0.001)]$ suggests that the suppressive effect of L-ornithine on distress vocalization was eliminated by co-administration with picrotoxin.

Table 3 shows the effect of L-ornithine and picrotoxin on various behavioral categories of chicks $10 \mathrm{~min}$ post-injection. L-Ornithine decreased active wakefulness 
$[\mathrm{F}(1,27)=30.885, \mathrm{P}<0.0001]$ while picrotoxin caused an increase $[\mathrm{F}(1,27)=61.453$, $\mathrm{P}<0.0001]$. A significant $[\mathrm{F}(1,27)=38.074, \mathrm{P}<0.0001]$ interaction between L-ornithine and picrotoxin was also detected. In addition, L-ornithine increased sleep-like behavior $[\mathrm{F}(1,27)=47.780, \mathrm{P}<0.001]$ while picrotoxin attenuated the effect of L-ornithine $[\mathrm{F}(1,27)=56.292, \mathrm{P}<0.0001]$. A significant $[\mathrm{F}(1,27)=48.015$, $\mathrm{P}<0.0001]$ interaction between L-ornithine and picrotoxin indicating that the hypnotic effect of L-ornithine was inhibited by co-administration with picrotoxin.

\section{Discussion}

We previously demonstrated that i.c.v. L-ornithine caused sedative and hypnotic effects under social isolation stress (Suenaga et al., 2008b, Kurauchi et al., 2009, 2010). In the present study, the magnitude of the anxiety induced by social separation stress was strengthened by i.c.v. CRF. According to Zhang et al. (2001b, 2003, 2004), CRF was acted in the brain just after i.c.v. injection. We also confirmed the response by CRF. The present results gave that L-ornithine attenuated mixed effect of CRF with isolation. In Experiment 1, we confirmed that the i.c.v. injection of L-ornithine can attenuate the stress response even under acute and strong stressful conditions induced by i.c.v. CRF (Fig. 1, Table 1). CRF is a key regulator of brain excitability changes associated with stress (Ehlers et al., 1983) and has been shown to activate the sympathetic nervous system and also to produce behavioral activation such as increased locomotor activity, induction of aggression and enhancement of arousal (Shibasaki et al., 1991; Sutton et al., 1982). Centrally administered CRF is capable of producing significant elevations in plasma adrenocorticotropic hormone, epinephrine and norepinephrine concentrations (Brown et al., 1982). Central CRF significantly elevated plasma corticosterone 
concentration implied that CRF activated the hypothalamic-pituitary-adrenal axis of chickens (Furuse et al., 1997). The present results suggest that L-ornithine can centrally reduce the stress response caused by CRF stimulation. Experiment 2 was conducted to confirm the effect of L-ornithine on modifying CRF-induced behavioral changes. Previously we have demonstrated that the effect of i.c.v. CRF can be attenuated by glucagon-like peptide-1 (Zhang et al., 2001b), norepinephrine (Zhang et al., 2003), serotonin (Zhang et al., 2004) and melatonin (Saito et al., 2005 b). We have confirmed that orally administered L-ornithine passes the blood brain barrier in mice (Kurata et al., unpublished data). Significant negative correlations between the dose of L-ornithine and CRF-stimulated stress responses (Fig. 2, Table 2) clearly suggest that L-ornithine might be a potential reagent to attenuate the CRF-induced stress behaviors. In Experiment 3, the results show that the sedative and hypnotic effects of L-ornithine are mediated via $\mathrm{GABA}_{\mathrm{A}}$ receptors.

The i.c.v. injection of putrescine, an L-ornithine metabolite, produced antidepressant-like effects in mice and these effects seem to be mediated through its interaction with the polyamine-site of $N$-Methyl- $D$-aspartate (NMDA) receptors (Zomkowski et al., 2006). The structure of L-ornithine is similar to that of putrescine. This suggests the possibility that L-ornithine might act on the polyamine-site of NMDA receptors if it is metabolized quickly enough (Suenaga et al., 2008b). However, putrescine contributed to the sedative, but not hypnotic, effect under social separation stress (Kurauchi et al., 2010). In the present study, picrotoxin attenuated the sedative and hypnotic effects of L-ornithine. Therefore, these effects of L-ornithine were almost completely induced by L-ornithine itself but not its metabolite.

Presently, $\mathrm{GABA}_{\mathrm{A}}$ receptor agonists are widely used as therapeutic agents for mood 
and sleep disorders such as anxiety and insomnia (Gross and Hen, 2004; Wilson and Nutt, 2007). $\mathrm{GABA}_{\mathrm{A}}$ receptors, the predominant inhibitory receptors in the central nervous system, are a family of ligand-gated transmembrane chloride channels. Activation of $\mathrm{GABA}_{\mathrm{A}}$ receptors by $\mathrm{GABA}$ or receptor agonists open the intrinsic chloride selective channel that triggers the influx of chloride ions, thus hyperpolarizing the neuron rendering it less capable of responding to excitatory neurotransmitters (Harrison, 2007). From the data presented here, L-ornithine could have therapeutic agents via the $\mathrm{GABA}_{\mathrm{A}}$ receptor.

\section{Conclusions}

In conclusion, the present results showed that the sedative and hypnotic effects of L-ornithine occurred via $\mathrm{GABA}_{\mathrm{A}}$ receptors. However, further mechanisms of L-ornithine on the $\mathrm{GABA}_{\mathrm{A}}$ receptor remain to be addressed, since it was unclear whether L-ornithine directly or indirectly acts at the $\mathrm{GABA}_{\mathrm{A}}$ receptor. Picrotoxin is suggested to interact with the chloride-selective pore, so antagonistic effect used in the present study is a non-competitive effect inhibiting the $\mathrm{GABA}_{\mathrm{A}}$ receptor activity of any agonist. Moreover, it was recently shown that the i.c.v. injected L-arginine, precursor of L-ornithine, increased both L-arginine and L-ornithine concentrations in the telencephalon and diencephalon in chicks 10 min post-injection (Suenaga et al., 2008b). However, the content of GABA was not changed. This suggests that the sedative and hypnotic effects of L-ornithine were not due to changes in GABA synthesis. Thus, the mechanism by which L-ornithine promotes sedative and hypnotic effects appears to involve the release of $\mathrm{GABA}$, reuptake inhibition of GABA or direct action on the $\mathrm{GABA}_{\mathrm{A}}$ receptors. If L-ornithine is used as an anxiolytic in the future, it is necessary to 
verify these possibilities.

\section{References}

Adachi N, Tomonaga S, Tachibana T, Denbow DM (2006) (-)-Epigallocatechin gallate attenuates acute stress responses through GABAergic system in the brain. Eur. J. Pharmacol. 531: 171-175.

Brown MR, Fisher LA, Spiess J, Rivier C, Rivier J, Vale W (1982) Corticotropin-releasing factor: actions on the sympathetic nervous system and metabolism. Endocrinology 111: 928-931.

Davis JL, Masuoka DT, Gerbrandt LK, Cherkin A (1979) Autoradiographic distribution of L-proline in chicks after intracerebral injection. Physiol. Behav. 22: 693-695.

Ehlers CL, Henriksen SJ, Wang M, Rivier J, Vale W, Bloom FE. (1983) Corticotropin releasing factor produces increases in brain excitability and convulsive seizures in rats. Brain Res. 278: 332-336.

Feltenstein MW, Lambdin LC, Ganzera M, Ranjith H, Dharmaratne W, Nanayakkara NP, Khan IA, Sufka KJ (2003) Anxiolytic properties of Piper methysticum extract samples and fractions in the chick social-separation-stress procedure. Phytother. Res. 17: 210-216.

Furuse M, Matsumoto M, Saito N, Sugahara K, Hasegawa S (1997) The central corticotropin-releasing factor and glucagons-like peptide-1 in food intake of the neonatal chicks. Eur. J. Pharmacol. 339: 211-214.

Gross C, Hen R (2004) The developmental origins of anxiety. Nat. Rev. Neurosci. 5: $545-552$.

Hamasu K, Haraguchi T, Kabuki Y, Adachi N, Tomonaga S, Sato H, Denbow DM, 
Furuse M (2009a) L-proline is a sedative regulator of acute stress in the brain of neonatal chicks. Amino Acids 37: 377-382.

Hamasu K, Shigemi K, Tsuneyoshi Y, Yamane H, Sato H, Denbow DM, Furuse M (2009b) Intracerebroventricular injection of L-proline and D-proline induces sedative and hypnotic effects by different mechanisms under an acute stressful condition in chicks. Amino Acids 38: 57-64.

Harrison NL (2007) Mechanisms of sleep induction by GABA A receptor agonists. J. Clin. Psychiatry 68: 6-12.

Koga Y, Takahashi H, Oikawa D, Tachibana T, Denbow DM, Furuse M (2005) Brain creatine functions to attenuate acute stress responses through gabanergic system in chicks. Neuroscience 132: 65-71.

Koutoku T, Takahashi H, Tomonaga S, Oikawa D, Saito S, Tachibana T, Han L, Hayamizu K, Denbow DM, Furuse M. (2005) Central administration of phosphatidylserine attenuates isolation stress-induced behavior in chicks. Neurochem. Int. 47: 183-189.

Kurauchi I, Shigemi K, Yamada S, Aoki M, Kawada Y, Morishita K, Denbow DM, Furuse M (2009) Comparison of central effects of L-ornithine metabolites on the stress responses of neonatal chicks. J. Anim. Vet. Adv. 8: 2580-2584.

Kurauchi I, Shigemi K, Kabuki Y, Hamasu K, Yamane H, Aoki M, Kawada Y, Morishita K, Denbow DM, Furuse M (2010) Central L-ornithine, but not polyamines, induces a hypnotic effect in neonatal chicks under acute stress. Nutr. Neurosci. 13: 17-20.

Morris SM Jr (2004) Enzymes of arginine metabolism. J. Nutr. 134: 2743S-2747S.

National Research Council (1994) Nutrient Requirements of Poultry. $9^{\text {th }}$ rev ed. National Academy Press, Washington, D.C. 
Pegg AE, McCann PP (1982) Polyamine metabolism and function. Am. J. Physiol. 243: C212-C221.

Richard D, Lin Q, Timofeeva E (2002) The corticotropine-releaseing factor family of peptides and CRF receptors: their roles in the regulation of energy balance. Eur. J. Pharmcol. 440: 189-197.

Saito S, Tachibana T, Choi YH, Denbow DM, Furuse M (2005a) ICV CRF and isolation stress differentially enhance plasma corticosterone concentrations in layer- and meat-type neonatal chicks. Comp. Biochem. Physiol. A 141: 305-309.

Saito S, Tachibana T, Choi YH, Denbow DM, Furuse M (2005b) ICV melatonin reduces acute stress responses in neonatal chicks. Behav. Brain Res. 165: 197-203.

Shibasaki T, Yamauchi N, Hotta M, Imaki T, Oda T, Ling N, Demura H (1991) Brain corticotropin-releasing hormone increases arousal in stress. Brain Res. 554: $352-354$.

Shigemi K, Tsuneyoshi Y, Hamasu K, Han L, Hayamizu K, Denbow DM, Furuse M (2008) L-Serine induces sedative and hypnotic effects acting at $\mathrm{GABA}_{\mathrm{A}}$ receptors in neonatal chicks. Eur. J. Pharmacol. 599: 86-90.

StatView, 1998. Version 5, SAS Institute, Cary, USA.

Suenaga R, Tomonaga S, Yamane H, Kurauchi I, Tsuneyoshi Y, Sato H, Denbow DM, Furuse M (2008a) Intracerebroventricular injection of L-arginine induces sedative and hypnotic effects under an acute stress in neonatal chicks. Amino Acids 35: $139-146$.

Suenaga R, Yamane H, Tomonaga S, Asechi M, Adachi N, Tsuneyoshi Y, Kurauchi I, Sato H, Denbow DM, Furuse M (2008b) Central L-arginine reduced stress responses are mediated by L-ornithine in neonatal chicks. Amino Acids 35: 107-113. 
Sutton RE, Koob GF, Moal ML, Rivier J, Vale W (1982) Corticotropin releasing factor produces behavioural activation in rats. Nature 297: 331-333.

Tabor CW, Tabor H (1984) Polyamines. Annu. Rev. Biochem. 53: 749-790.

Takagi T, Bungo T, Tachibana T, Saito E-S, Saito S, Yamasaki I, Tomonaga S, Denbow

DM, Furuse M (2003) Intracerebroventricular administration of GABA-A and

GABA-B receptor antagonists attenuate feeding and sleep-like behavior induced by

L-pipecolic acid in the neonatal chick. J. Neurosci. Res. 73: 270-275.

van Luijtelaar ELJM, van Der Grinten CPM, Blokhuis HJ, Coenen AM (1987) Sleep in the domestic hen (Gallus domesticus). Physiol. Behav. 41: 409-414.

Wilson S, Nutt D (2007) Management of insomnia: treatments and mechanisms. Br J Psychiatry 191: 195-197.

Yamane H, Tsuneyoshi Y, Denbow DM, Furuse M (2009) N-Methyl-D-aspartate and $\alpha$-amino-3-hydroxy-5-methyl-4-isoxazolepropionate receptors involved in the induction of sedative effects under an acute stress in neonatal chicks. Amino Acids 37, 733-739.

Zhang R, Nakanishi T, Ohgushi A, Ando R, Yoshimatsu T, Denbow DM, Furuse M (2001a) Suppression of food intake induced by corticotropin-releasing factor family in neonatal chicks. Eur. J. Pharmacol. 427: 37-41.

Zhang R, Nakanishi T, Ohgushi A, Ando R, Yoshimatsu T, Denbow DM, Furuse M (2001b) Interaction of corticotropin-releasing factor and glucagon-like peptide-1 on behaviors in chicks. Eur. J. Pharmacol. 430: 73-78.

Zhang R, Tachibana T, Takagi T, Koutoku T, Denbow DM, Furuse M (2003) Centrally administered norepinephrine modifies the behavior induced by corticotropin-releasing factor in neonatal chicks. J. Neurosci. Res. 74: 630-636. 
Zhang R, Tachibana T, Takagi T, Koutoku T, Denbow DM, Furuse M (2004) Serotonin modifies corticotropin-releasing factor-induced behaviors of chicks. Behav. Brain Res. 151: 47-52.

Zomkowski ADE, Santos ARS, Rodrigues ALS (2006) Putrescine produces antidepressant-like effects in the forced swimming test and in the tail suspension test in mice. Prog. Neuropsychopharmacol. Biol. Psychiatry 30: 1419-1425. 


\section{Figure Legends}

Fig. 1. Effect of i.c.v. injection of either vehicle, CRF, L-ornithine, or CRF plus L-ornithine on total distress vocalizations during $10 \mathrm{~min}$ isolation in 4-day-old layer chicks. Results are expressed as means \pm S.E.M. The number of chicks used in each group was 6 or 7 . Groups with different letters are significantly different $(\mathrm{P}<0.05)$.

Fig. 2. Effect of i.c.v. injection of either vehicle, $0.01 \mu \mathrm{g}$ of $\mathrm{CRF}$ alone, or $0.01 \mu \mathrm{g}$ of CRF plus $0.125,0.25$, or $0.5 \mu \mathrm{mol}$ of L-ornithine on total distress vocalizations during $10 \mathrm{~min}$ isolation in 4-day-old layer chicks. Results are expressed as means \pm S.E.M. The number of chicks used in each group was 6 or 7 . Groups with different letters are significantly different $(\mathrm{P}<0.05)$. Distress vocalizations $($ count/10 $\mathrm{min})=607.739$ (S.E. 74.463) 1195.367 (S.E. 251.387) X $\left(\mathrm{R}^{2}=0.485, \mathrm{P}<0.0001\right)$

Fig. 3. Effect of i.c.v. injection of either $0.01 \mu \mathrm{g}$ of CRF alone or $0.01 \mu \mathrm{g}$ of CRF plus 0.5 $\mu$ mol of L-ornithine, CRF plus $500 \mathrm{ng}$ of picrotoxin, or CRF puls $0.5 \mu \mathrm{mol}$ of L-ornithine with $500 \mathrm{ng}$ of picrotoxin on total distress vocalizations during $10 \mathrm{~min}$ isolation in 5-day-old layer chicks. Results are expressed as means \pm S.E.M. The number of chicks used in each group was 6 or 7 . Groups with different letters are significantly different $(\mathrm{P}<0.05)$. 


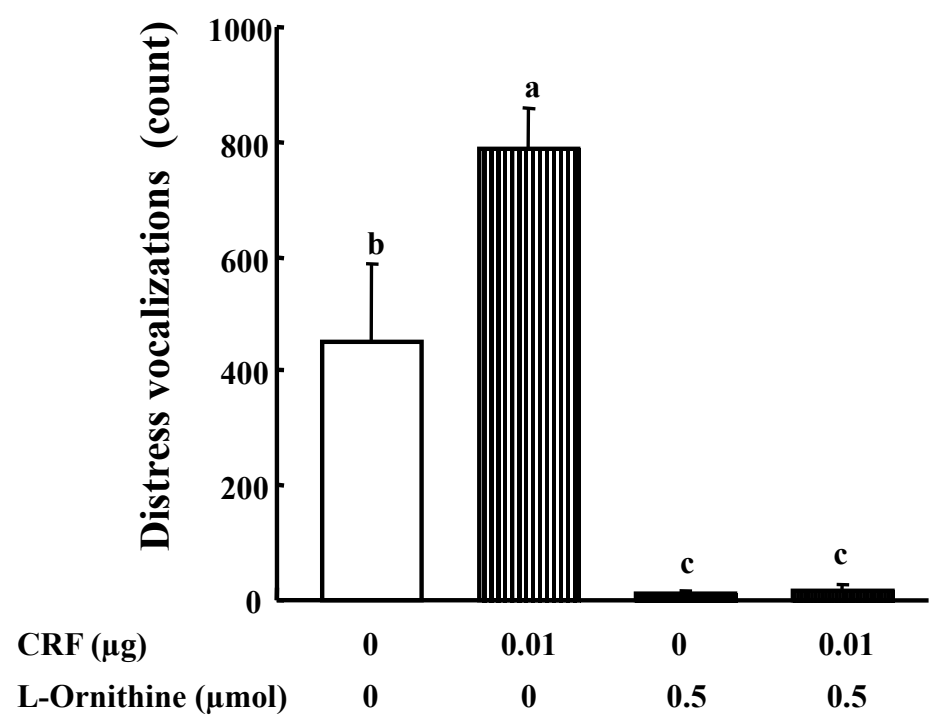

Fig. 1 


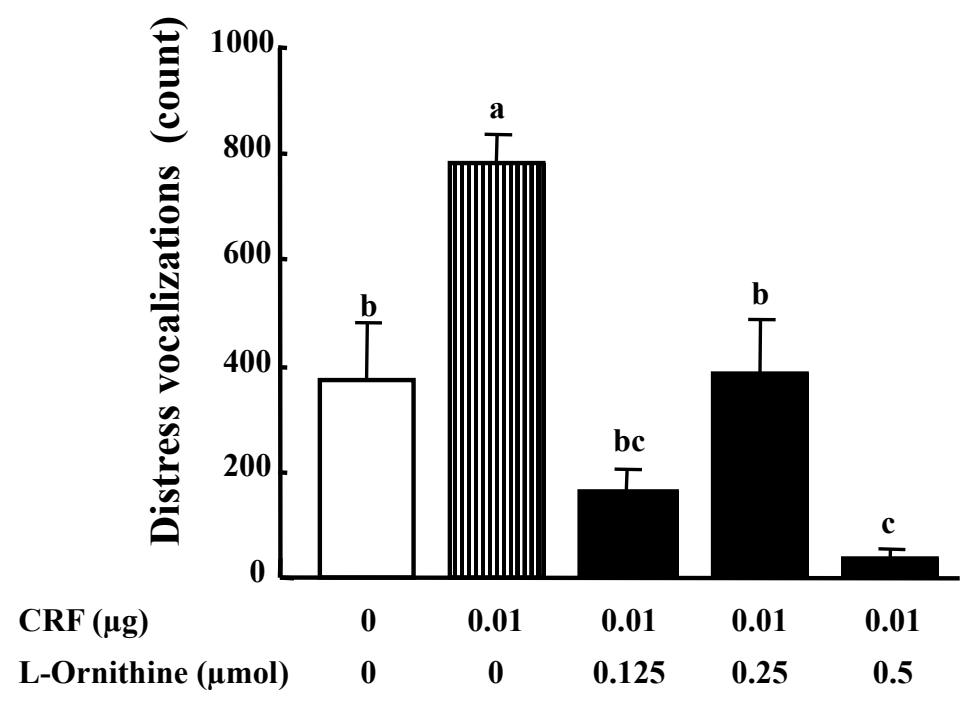

Fig. 2 


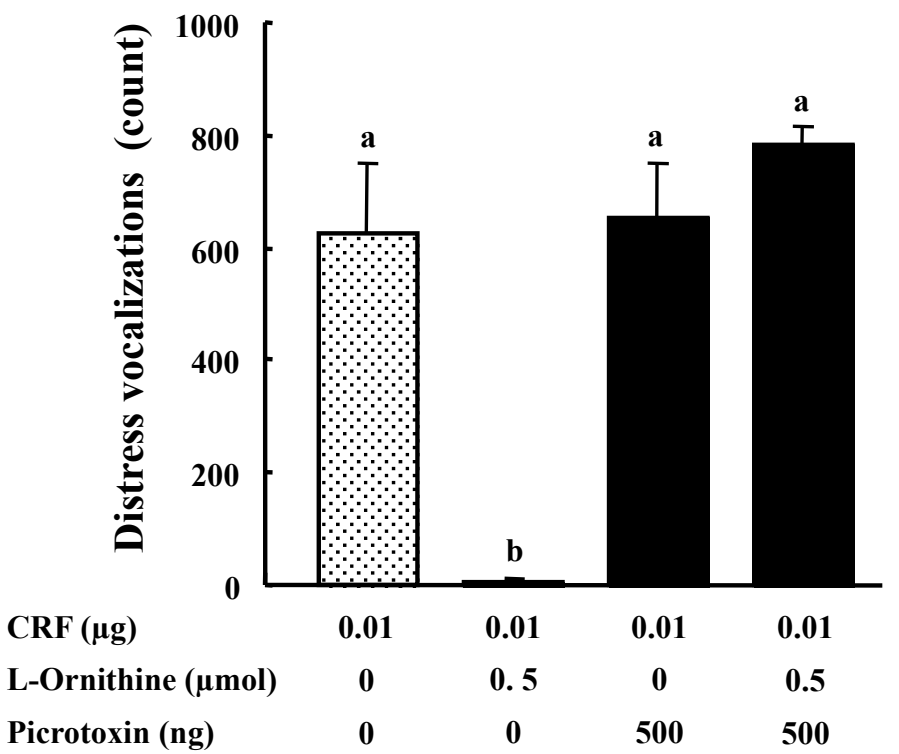

Fig. 3 
Table 1. Effect of i.c.v. injection of L-ornithine and CRF on various behavioral categories of 4-day-old chicks in response to social separation stress for $10 \min ^{1}$

\begin{tabular}{|c|c|c|c|c|c|c|c|}
\hline $\mathrm{CRF}(\mu \mathrm{g})$ & \multicolumn{2}{|c|}{ Vehicle } & \multicolumn{2}{|c|}{ L-Ornithine $(0.5 \mu \mathrm{mol})$} & \multicolumn{3}{|c|}{ P-value } \\
\hline $\begin{array}{l}\text { Standing/sitting motionless with eyes } \\
\text { open }\end{array}$ & $213 \pm 64$ & $87 \pm 27$ & $144 \pm 35$ & $115 \pm 34$ & NS & NS & NS \\
\hline $\begin{array}{l}\text { Sitting motionless with head drooped } \\
\text { (sleep-like behavior) }\end{array}$ & $76 \pm 68^{b}$ & $0^{\mathrm{b}}$ & $420 \pm 52^{\mathrm{a}}$ & $443 \pm 49^{\mathrm{a}}$ & $<0.0001$ & NS & NS \\
\hline Total & 600 & 600 & 600 & 600 & & & \\
\hline
\end{tabular}

${ }^{1}$ Values are means \pm S.E.M. in seconds. The number of chicks used in each group was 6 . Groups with different letters are significantly different $(\mathrm{P}<0.05)$ by Tukey-Kramer test. 
Table 2. Effect of i.c.v. injection of L-ornithine and CRF on various behavioral categories of 4-day-old chicks in response to social separation stress for $10 \min ^{1}$

\begin{tabular}{|c|c|c|c|c|c|}
\hline $\mathrm{CRF}(\mu \mathrm{g})$ & 0 & 0.01 & 0.01 & 0.01 & 0.01 \\
\hline L-Ornithine $(\mu \mathrm{mol})$ & 0 & 0 & 0.125 & 0.25 & 0.5 \\
\hline Active wakefulness & $287 \pm 70^{\mathrm{ab}}$ & $490 \pm 21^{\mathrm{a}}$ & $127 \pm 29^{b}$ & $251 \pm 75^{\mathrm{b}}$ & $77 \pm 37^{\mathrm{b}}$ \\
\hline $\begin{array}{l}\text { Standing/sitting motionless with eyes } \\
\text { open }\end{array}$ & $220 \pm 32^{\mathrm{ab}}$ & $110 \pm 21^{b}$ & $328 \pm 59^{\mathrm{a}}$ & $242 \pm 42^{\mathrm{ab}}$ & $167 \pm 34^{\mathrm{ab}}$ \\
\hline Standing motionless with eyes closed & $13 \pm 9$ & 0 & 0 & $5 \pm 5$ & 0 \\
\hline $\begin{array}{l}\text { Sitting motionless with head drooped } \\
\text { (sleep-like behavior) }\end{array}$ & $80 \pm 40^{b}$ & $0^{\mathrm{b}}$ & $145 \pm 55^{\mathrm{b}}$ & $102 \pm 54^{\mathrm{b}}$ & $356 \pm 66^{\mathrm{a}}$ \\
\hline Total & 600 & 600 & 600 & 600 & 600 \\
\hline
\end{tabular}

${ }^{1}$ Values are means \pm S.E.M. in seconds. The number of chicks used in each group was 6 . Groups with different letters are significantly different $(\mathrm{P}<0.05)$ by Tukey-Kramer test. $\quad$ Active wakefulness $($ second $/ 10 \mathrm{~min})=380.233($ S.E. 49.215$)-648.011($ S.E. 166.149$) X\left(\mathrm{R}^{2}=0.388\right.$, $\mathrm{P}<0.001)$. Sleep-like behavior $($ second $/ 10 \mathrm{~min})=3.983($ S.E. 42.876$)+661.909\left(\right.$ S.E. 144.747) $\mathrm{X}\left(\mathrm{R}^{2}=0.466, \mathrm{P}<0.0001\right)$. 
Table 3. Effect of i.c.v. injection of CRF, L-ornithine and picrotoxin on various behavioral categories of 5-day-old chicks in response to social separation stress for $10 \mathrm{~min}^{1}$

\begin{tabular}{|c|c|c|c|c|c|c|c|}
\hline \multirow[b]{2}{*}{ Picrotoxin (ng) } & \multicolumn{2}{|c|}{ CRF $(0.01 \mu \mathrm{g})$} & \multicolumn{2}{|c|}{ L-Ornithine $(0.5 \mu \mathrm{mol})$} & \multicolumn{3}{|c|}{$\mathrm{P}$-value } \\
\hline & 0 & 500 & 0 & 500 & L-Ornithine & picrotoxin & $\begin{array}{c}\text { L-Ornithine } \\
+ \\
\text { picrotoxin } \\
\end{array}$ \\
\hline Active wakefulness & $452 \pm 65^{\mathrm{a}}$ & $513 \pm 33^{\mathrm{a}}$ & $21 \pm 6^{b}$ & $535 \pm 10^{\mathrm{a}}$ & $<0.0001$ & $<0.0001$ & $<0.0001$ \\
\hline $\begin{array}{l}\text { Standing/sitting motionless with eyes } \\
\text { open }\end{array}$ & $131 \pm 49$ & $87 \pm 32$ & $153 \pm 58$ & $65 \pm 10$ & NS & NS & NS \\
\hline Standing motionless with eyes closed & $1 \pm 1$ & 0 & 0 & 0 & NS & NS & NS \\
\hline $\begin{array}{l}\text { Sitting motionless with head drooped } \\
\text { (sleep-like behavior) }\end{array}$ & $17 \pm 17^{\mathrm{b}}$ & $1 \pm 1^{\mathrm{b}}$ & $426 \pm 63^{a}$ & $0^{\mathrm{b}}$ & $<0.0001$ & $<0.0001$ & $<0.0001$ \\
\hline Total & 600 & 600 & 600 & 600 & & & \\
\hline
\end{tabular}

${ }^{1}$ Values are means \pm S.E.M. in seconds. The number of chicks used in each group was 6. Groups with different letters are significantly different $(\mathrm{P}<0.05)$ by Tukey-Kramer test. 